\section{B A Institute of \\ YK Business Administration \\ 六下 \\ Karachi \\ Leadership and Ideas for Tomorrow}

Business Review

Volume 7 Issue 1 January-June 2012

$1-1-2012$

\title{
Disaster management issues of Pakistan : An analytical view for a viable way forward
}

\author{
Bashir Ahmad \\ Gwadar Institute of Technology, Gwadar, Pakistan
}

Follow this and additional works at: https://ir.iba.edu.pk/businessreview

Part of the Emergency and Disaster Management Commons, Public Affairs Commons, and the Social Welfare Commons

\section{(c) (1)}

This work is licensed under a Creative Commons Attribution 4.0 International License.

\section{Recommended Citation}

Ahmad, B. (2012). Disaster management issues of Pakistan : An analytical view for a viable way forward. Business Review, 7(1), 64-81. Retrieved from https://doi.org/10.54784/1990-6587.1302 


\title{
ARTICLE
}

\section{Disaster Management Issues of Pakistan : An Analytical View for a Viable Way Forward}

\author{
Bashir Ahmad \\ Gwadar Institute of Technology, Gwadar, Pakistan
}

\begin{abstract}
Disaster management is a dilemma in Pakistan; despite having experienced number of natural and manmade disasters in its short history, we are far off from the satisfactory arrangements. With all the policies and strategies worked out in apparent details/claims, we fall prey to paralysis at the time of occurrence. The point of concern is collapse of the system when it is required to put to practice. This leads to chaotic situation whereby despite having abundance inflows of resources/ means, our management system at the site of occurrence fails to respond.

This research paper aims at detailed analysis of the issue and put forward solution in the management domain through which we can attain optimum results under resource constraints. On one hand, where the paper highlights drawbacks in the existing system; it also beings under discussion the strong points of the systems being followed in the contemporary world. At the end, the paper presents viable options and measures for improving our own system while remaining within our resource constraints.
\end{abstract}

"Not even windstorm, earth-tremor or rush of water is catastrophic. A catastrophic is known by its works; that is, to say, by the occurrence of disaster. So long as the ship rides out of the storm, so long as the city resists the earth-shocks, so long as the leaves hold, there is no disaster. It is the collapse of the cultural protections that constitutes the disaster proper."

Edward Hallett Carr

\section{Disaster Management - Meaning and Scope}

Oxford Dictionary defines the word 'disaster' as sudden or great misfortune; an event of ruinous or distressing nature leading to a calamity - complete failure. Oxford Talking Dictionary, 1998, The Learning Company, Inc. Its roots can be found in French 'dus' (bad) and 'aster' (star) meaning by 'bad star' or 'bad luck'. The perception of 'bad star' comes from the Greek and has an astrological tale attached to it, in which, ancient Greeks used to refer the incident to destruction of a star, which was believed to bring a misfortune to the people on earth, causing enormous devastation to human lives. Within the defined parameters of misfortune leading to destructiveness, essence of word 'disaster' highlights two criteria i.e. mishap or reverse of fortune encompassing adversities of great nature and failure of the system to respond timely and effectively. The distressing state of damage and complete failure of the system as per word meaning of 'disaster' appear conditional to each other for the development of a disastrous situation. This is to imply that if in a situation of calamity, the system remains intact and functioning, it is not a disaster. Contrarily if the system breaks 
down to an extent that functionalities of human lives are disrupted - leading to a situation of chaos and confusion, it is to be considered a disaster. Here, mentioning the system as failure is also to amplify the suddenness and great nature of damage which makes the system to collapse wholly or partially. It therefore refers 'disaster' to be an event of substantial damage or destruction including loss of lives as well as drastic changes in the environment.

The United Nations rather work on a more candid definition of disaster as "a serious disruption of the functioning of society, causing widespread human, material or environmental losses which exceed the ability of the affected people to cope using its own resources." This definition is concise elaboration of the word meaning of 'disaster' as mentioned above in the first paragraph; referring the devastation as beyond local capacity, meaning by, failure or collapse of the system. The Australian Society defines disaster as "a serious disruption to community life which threatens or causes death or injury, in that damage to property is beyond the day to day capacity of the prescribed statutory authorities, which requires special mobilisation and organisation of resources other than those normally available to those authorities". Notwithstanding the way 'disaster' has been defined, its essence conveys a serious state of affairs which is beyond the normal capacity of the affected community and warrants external assistance. The damage caused by the disasters is immeasurable and it varies with the geographical location, climate and type of terrain of the affected area. Its characteristics are: unpredictability, speed and high intensity.

The word 'management' on the other hand, comes from the Italian 'maneggiare' which means to handle - especially the tools. The French word 'mesnagement' later 'menagement' also influenced the development of the meaning of the English word 'management' in 18th century. In essence, 'management' means organization and coordination of activities of an enterprise according to set procedures for the purpose of achieving certain objectives. Mary Parker Follet defines 'management' as the art of getting things done through people. In the obtaining scientific world, management is regarded as a distinct process encompassing activities of planning, organising, actuating and controlling to determine and complete certain objectives. Putting both the words (disaster and management) together, 'Disaster Management' would mean undertaking certain actions and coordinating activities so as to take safeguards and if it occurs so then to restore the system's functioning which was disrupted due to sudden devastation and damage. The restoration of system's functioning implies bringing back socio - economic activities of the people; to mainly include restoration of essential services like water supply, electricity, gas (where it was connected), sewerage system, traffic, functioning of hospitals, schools, commercial activities, governance machineries and communication systems.

It is worth mentioning here that in disaster, hazards leading to deplorable situations are related to vulnerabilities of human areas of concern. For example earthquake or volcanic eruptions occurring in deep sea or in mountains away from the human inhabitations are not regarded as disasters. At the same time, damages caused in hazards are the consequence of insufficiently managed risks. Scholars like B. Wisher relate disastrous events with the vulnerabilities of human inhabitations when they say; "Disasters occur when hazards meet vulnerability". Therefore hazards are not disasters till the time they happen in the vulnerable areas of human concerns. Pakistan is vulnerable to variety of disasters, which may be natural or human induced. Apart from numerous human-induced disasters including accidents of all kinds and fires etcetera, since 1954 to 2004, Pakistan faced 16 cyclones, 4 major droughts, 18 earthquakes, 33 floods, 10 landslides, 12 extreme temperatures and 6 epidemics. In the last decade (1993 to 2002), we lost 6037 lives and closer to a million people were otherwise affected due to disasters. 


\begin{abstract}
Aim
To study disaster management issues of Pakistan, carryout their in-depth analysis in relation with disaster management strategies being followed in the contemporary world and recommend a way forward.

\section{Scope of the Study}

The study basically focuses on the psycho-socio makeup of our society, our societal attitudes to calamities and the displayed behaviour during the relief and rehabilitation process of disasters. Cardinal areas of emphasis are:-

- Our national psyche and approach towards hazards.

- Types of disasters typically those of Pakistan's concerns and their characteristics.

- $\quad$ Existing mechanism of disaster management in our country.

- Disaster management in the contemporary world.

- $\quad$ Recommended approach towards disaster management.
\end{abstract}

\title{
Our National Psyche and Approach towards hazards
}

\section{The Population Factor}

Pakistan's population is approximately 187 millions which makes it the 6th most populous country in the world The growth rate of $1.6 \%$ implies, fast addition in the overall population, may go over 200 million in next about $15-20$ years. The ever increasing quantum of population has negative impact on the available meagre resources in terms of infrastructure and rehabilitation means. According to 'Human Development Report' of UNDP (United Nations Development Programme), published in 2009, 63\% of Pakistan's population lives on less than $\$ 2$ a day. The overgrowth of population in rural areas has given rise to rapid urbanisation, especially in the last about three decades; converting small cities into megacities and towns / villages into small and medium size cities etcetera. The megacities have almost become unmanageable. This has also resulted into distinct densely and sparsely populated pockets / areas. For example in the south, larger population is along Indus (river) and Karachi. In the north, dense population resides in areas like Faisalabad, Lahore, Gujranwala, Sialkot, Rawalpindi, Nowshera, Mardan and Peshawar. This uneven inhabitation of population has implications for disaster management especially under resource constrains. The two factors (population and its uneven distribution) when put together, have following implications on crisis management as and when it occurs.

Firstly, the overpopulated areas suffer due to un-employability of crisis control means in restricted and irregularly constructed buildings, having narrow streets and congested entryexit points. Fire break outs in Lahore (Shah Alam Market) and Karachi (Markets on MA Jinnah Road) are the recent examples where it could not be controlled in time due to difficult employability of fire extinguishing means. The over populated area are otherwise difficult to manage in terms of civic services and traffic controls etcetera. When confronted with emergency situations, maximum casualties occur due to suffocation and belated evacuation. The streets get narrower with the passage of time due to unchecked encroachment under overwhelming population pressures. During disastrous situations, these turn into death traps.

Secondly, the sparsely populated areas suffer due to delayed availability of relief means. All the commodities, supporting social structure of human lives, are manufactured and located in / around the major population centres for obvious reasons. As and when some 
calamity takes place in sparsely populated areas, the supportive means available in the surrounding areas fall short of the requirement. So they have to be transported from the far flung areas, which take more time and efforts. Similarly the volunteer social welfare / support organizations including NGOs are also located in bigger cities. Their mobilization as well as that of government machinery takes time, resultantly the immediately required help including evacuation gets delayed.

Therefore densely and sparsely populated inhabitations; both pose a problem for disaster management in either ways as mentioned above. The solution lies in adopting a balance in developing and managing cities / population centres.

\section{The Society of Pakistan Socio - Psycho Factor}

Pakistan is a multicultural, predominantly Muslim society with complex ethnicity. Its social behaviour is based on caste, creed, tribe, language, area and financial status of individuals. This is within communities forming provincial units and the federal levels, provincialism prevails over the nationalism. This has implications for distribution of national resources and management of material means, particularly so upon occurrence of calamities. The country, at the same time, is blessed with land of all kinds to include lofty mountains, plains (especially river corridors), valleys, seashores and jungles.

Ethnicity and landscape as mentioned above have influence on psychological makeup of various communities residing in Pakistan. Accordingly the social behaviour of these communities shapes the national psyche which ultimately leads to the national character for responses to the confronted situations. The predominantly illiterate society which lacks foresightedness and scientific knowledge in particular does not think beyond today. Tomorrow, for them, is to be seen as and when it would come. The stereotype education system does not make the people think and ask questions as to why and how. Building houses in the riverbeds, for example, does not alarm them of the consequences of floods as happened during devastating torrential rains in 2010 which swept away settlements and inhabitations in great numbers.

Scarcity of political vision with deep rooted bureaucratic system leading to intermittent autocracy adds to the adversity of environment. This leaves the society deficient of self actualization, which means to work under strict supervision / compulsions and for every developmental work, dependence be rested on the government machinery. Another reason of this kind of mindset is that remaining under the rules of emperors and lords, the society, by and large, managed in isolation, alien to the system of governance. Consequently the resultant divergence between state and society does not allow ownership of government created infrastructures and actions / policies at the community levels. Ignorance of rural areas under the influence of landlord segment of the society has negative impacts on the demographic landscape. Uncontrolled migration to cities has created slums and crime dens in / around the urban pockets. These inhabitations impact negatively under crisis. The overriding factor is attitude of the society as a whole which needs a change to understand societal obligations and share responsibilities - ownership in coordination with the government responses.

\section{Types of Disasters and Their Characteristics}

Every catastrophic event for which protective systems devised by the communities fail to respond is a disaster; going by analogy, all disasters are due to human errors, rather lack of capacities. Catastrophes or hazards by themselves do not necessarily lead to disastrous situations, they become so when population is unprepared to respond and take protective measures. Consequently they get severely affected, leading to unprecedented causalities and 
losses which ultimately require outside help for evacuation and rehabilitation of infrastructure. The disasters can either be classified according to their genesis or nature of occurrence. A joint study carried out by COMSATS Institute of Information Technology Abbottabad and Institute of Development Studies Agriculture University Peshawar classifies hazards on the basis of their genesis like geological category includes earthquakes, tsunami, volcanic eruption, landslides, dam bursts and mine fires. Similarly water and climatic hazards encompass cyclones, tornadoes, hurricanes, floods, droughts, hailstorms, cloudbursts, heat and cold waves, avalanches and sea erosions. Biological category encompasses environmental pollutions, deforestations, epidemics, pest attacks, desertification, food poisoning and biological warfare means. Chemical and industrial accidents include oil spills and fires, poisonous gasses and radiations. Finally accident related disasters are road / track accidents, air crashes, bomb blasts, building collapse, electric accidents and festival related accidents. According to nature and causes of occurrences, hazards can broadly be divided into two basic categories i.e. natural and man-made which also include categories under the basis of genesis. These have been briefly explained in the following paragraphs:-

- Natural Disasters take place due to natural calamities, their nature of occurrence and main characteristics are given below:-

- Earthquakes are the results of collision of tectonic plates which can result into wide spread of fires, seismic sea waves and volcanoes leading to destruction of infrastructures and causing casualties. Their sudden occurrence leaves very less reaction time for the people to get out of the buildings and take safeguards. The earthquakes occurring at nights especially of winters are more fatal than those during daylight hours. Pakistan faced Earthquakes in 1974, 1990, 2004 and Servest one in 2005 which shook the entire world. Main characteristics of the earthquakes are suddenness, unknown psychological fear, colossal damage / destruction to the buildings and earth surface.

- Volcanic Eruptions occur when earth surface is torn apart by lava which destroys the living beings and infrastructure over its area of spread. Reaction time to take safeguards depends upon the speed with which lava spreads. The ash even when it cools down forms a cloud over the nearby localities. When it mixes up with water, it makes concrete like material through chemical reactions. The extremely hot material spreading over the earth causes fires and burials.

- Avalanche is sudden fall of snow slide over human inhabitations or valleys causing human and material causalities. Occurrence of avalanche is sudden and it takes along a huge quantity of earth surface material over a large area. Its main characteristics are high speed, enormous volume of mud and slush and frightening sounds causing psychological helplessness.

- Floods occur due to excessive flow of water which is beyond the capacity of existing water channels. In Pakistan floods of 1950, 1992, 1998 and 2010 are famous which caused human and material causalities at large scales. River related floods are more severe in Punjab and Sind Provinces whereas hill torrents are common in KPK (Khyber Pukhtoon Khwa), Balochistan and Northern Areas of the country. Mostly floods turn into disasters in summers during monsoon. Under normal circumstances, floods give sufficient reaction time for taking safeguards. Their effects are displacement of people, destruction of infrastructure, human and animal casualties, damage to the crops, disruption in education schedules, devastating effects on sewerage system and roads, damage to the civil services infrastructure and consequently spread of epidemics.

- Cyclones occur due to extensive flooding and storm surges which may cause sea intrusions. Examples are Bhola Cyclone which struck Bangladesh (then East Pakistan) 
in 1970, Hurricane Katrina which caused huge damage to New Orleans in 2005 and Cyclone Yasi which struck Australia in 2011. Cyclones provide time for the people to take safeguards, provided there is a system of forewarning in place. However it does not allow complete evacuation of the affected areas. Coastal belts of Sind and Balochistan are worst hit by cyclones like the one in 1999 which hit Thatta and Badin districts and destroyed 73 settlements and incurred economic loss worth \$ 12.5 million.

- Limnic Eruptions occur when gases like CO2 suddenly erupt from deep lake waters causing suffocation. It can cause water disruptions inside the water bodies leading to tsunamis. Larger landslides, volcanic activities or explosions can lead to the causes of limnic eruptions.

- Tsunamis are usually caused by the undersea earthquakes. These can also occur due to large scale land sliding. The Tsunami which caused havoc occurred in Indonesia at Sumatra in October 2010. Its main characteristics are unpredictability and sudden inundations. Pakistan has no history of disasters occurring out of Tsunamis; however it can occur against coastal belt inhabitations for which we need to be mindful.

- $\quad$ Blizzards are characterised by low temperatures and strong winds which results into heavy snowfalls. In blizzards, the wind speed is much higher which makes it different from the snow storms. It reduces the visibility which results into complete or partial breakdown of human lives' functioning. In 1972, Iran faced severe blizzard which lasted for about 7 days and caused 4000 deaths. Northern areas of Pakistan can face disasters coming out of blizzards.

- Drought is the result of severe and prolonged dry spell which reduces availability of water beyond minimum required levels. Drought conditions may spread over years like the one which caught some states of Australia in 2006. In the same year, China also faced drought in Sichuan Province which affected approximately 8 million people and 7 million cattle. Arid and semi arid areas of Pakistan especially most of the districts of Balochistan, southern parts of Sind and Punjab receive very less rainfalls and at times dry spells spread over years which result into droughts like those of 2000 and 2002 which destroyed livelihood of thousands of people including their livestock and crops. Approximately 15 million cattle died of this drought causing an economic loss of $\$ 2.5$ billion. Droughts cause large scale migrations and casualties to livestock.

- Heat Waves occur due to prolonged high temperatures which results into deficiency of water leading to heat strokes. It also results into bushfires which may spread over many days and areas. Pakistan faces heat waves almost every year in parts of Sindh and Balochistan and some casualties due to heatstroke and deficiency of water.

- Tornadoes are violent rotating columns of air which are in contact with surface of the earth as well as cumulonimbus clouds. Mostly they take the shape of a rotating funnels of air which sucks the infrastructure inwards and uproots the trees as well manmade things. They do not give reaction time for safeguards and cause sudden damages.

- Fires here mean uncontrollable wildfires which may be caused by the lightening and droughts. Fires can also occur due to human negligence.

- $\quad$ Epidemic is outbreak of contactable diseases which spread from person to person rapidly. It spreads with much higher rate in thickly populated areas and turns into a disaster when patients become more than the capacity of hospitals, paramedic staff and required categories of medicines. Epidemics mostly relate to common diseases spreading rapidly and extensively by infections. Swine flu i.e. H1N1 influenza is an example of epidemic 
which spread in most part of the World in 2009 -2010. Other common diseases may include malaria, dengue fever and bird flu etcetera. It also psychologically affects the people of those particular areas.

- Famines occur due to scarcity of food including water for human beings as well as animals. It can be due to prolonged dry spells which destroys crops or reduce yields substantially or due to over population in an area where food stuff falls below the minimum requirements.

- Landslides, in most of the cases, occur due to earthquakes, volcanic eruptions and general changes in the ground environments as a result of heavy rains or storms etcetera. Landslides turn into disasters when ground elements like rocks, trees and parts of manmade infrastructure are swept down over inhabitations or road networks etcetera. The consequences of landslides are human and animal causalities, damage to infrastructures like building, roads and bridges etcetera. Until and unless detected in time, landslides give no reaction time to residents. Evacuation and subsequently rehabilitation is effortintensive and costly affair. Pyroclastic flows in thick density cause burial of localities. In 1953, Tangiwai disaster was caused by mudflows. Similarly 1985, the town of Armero was buried due to sudden mudflow and landslides causing approximately 23000 casualties.

Manmade Disasters occur due to human activities or errors. The common and consciously / unconsciously human induced disasters are covered in the succeeding paragraphs:-

- Environmental Pollutions occur due to human activities which negatively impact the nature. It includes release of gasses due to chemical actions of industrial activities, automobiles' smokes and solid, sewerage and industrial wastages. Environmental pollutions like poisonous gasses have immediate effects. However effects due to change in environments are slow like global warming etcetera. Consequently the environmental changes give rise to disasters like excessive melting resulting into floods, heat waves and extreme temperatures.

- Deforestation refers to large scale removal of trees to clear the land for building infrastructure or cutting woods for human consumption. Deforestation has no direct and immediate hazards; however it brings changes in the environments which may ultimately lead to disastrous conditions like scarcity of rainfalls and water etcetera.

- Industrial Accidents occur due to malfunctioning of mechanical means of industrial units which may result into eruption of large scale chemical spoils, infrastructural collapse, leakages of poisonous gases, explosions, release of dangerous radiations etcetera. Industrial accidents do not give much reaction time for taking necessary safeguards or undertake clearance of the area. At the same time each category of the hazard within industrial accidents require special handling, equipment, specifically trained manpower and degree of awareness amongst the people to take individual protective measures.

- Collapse of Residential and Commercial Buildings may occur as a result of air crashes like 9/11, nuclear explosions or environmental / human errors. Such collapses cause large scale human causalities and infrastructural damages. Due to debris, evacuation operations are difficult and time taking. It also requires special mechanical means and trained manpower to handle the situations.

- Air Crashes are the sudden disasters with little chances of survivals. Evacuations of casualties is challenging and time taking especially once such incidents occur in difficult terrain like 'Air Blue' air crash in 2010 in Margala Hills, Islamabad. Management 
of affairs at the air crash site and air ports is patience demanding and tedious job.

- Road and Rail Accidents turns into disasters when these involve large number of vehicles / bogies collide with each other and traffic comes to stand still. The challenging tasks are evacuation of human and vehicular casualties, restoration of traffic flows and measures for salvage of the site against thefts and plunders.

- Border Disputes affect the civilian population and involve their temporary relocation. Their properties both movable and immovable become a source of concern because they do not want to leave movable properties behind and retain presence over immovable ones.

- Refugees Problems may occur due to border disputes as well as security situation where own forces have to go in to restore government's writ and authority. Issues related to disaster management are evacuation of the civil population from the affected areas, their temporary settlement at the new sites and rehabilitation at subsequent stages.

- Terrorism creates disastrous situations where it involves indiscriminate firing, resulting into large scale killings, use of explosives to destroy infrastructures and suicide bombing to cause human and material casualties. The disastrous state under terrorism has distinct characteristics of psychological impact on the civil population as well as law enforcing agencies. An efficient disaster management warrants speedy evacuation of casualties, collection of witnessing material and clearance of the area for restoration of routine life.

- Internal Security basically refers to a state where functionalities of the civil administration collapse and extraordinary measures have to be called in, to restore control and functioning of civil services. It can be a situation of large scale thefts and operation of the dacoits where civil population takes the law in their own hands. The anti state elements operating in the area add to adversities may be on the behest of foreign elements. In our case the prevailing situation of law and order in Karachi over the last one year is a case in point of internal security concerns.

- Civil War is an outcome of the social injustice, nepotism, corruption and poor governance leading to initially law and order and subsequently leading to large scale casualties and damage to properties. Managing civil war disasters is difficult till the times its roots / causes are not addressed. Unmanaged civil war disaster may lead to collapse of the state system like emergence of Bangladesh out of East Pakistan in 1971.

\section{Disaster Management in Pakistan}

\section{Disaster Management Policies / Plans till Earthquake 2005}

Despite facing the first flood in 1950, just three years after creation of Pakistan, the successive governments could not devise any comprehensive strategy to deal with disastrous situations. Disaster management policies, developed over the years, at the federal and provincial levels were primarily focused on flood relief operations. Government of Pakistan, A Review of Disaster Management Policies and Systems in Pakistan, January 2005, Islamabad.

The first formal forum, to address the calamities, was established in 1970, under the Cabinet Division with the name of 'Emergency Relief Cell'. The Cell drafted first 'National Disaster Plan' in 1974, which was mandated to establish procedures, make organizational set-ups and fix responsibilities for implementation of strategies for emergency relief operations. This was followed by 'Federal Flood Commission' which came on ground in late 70 s. 
The department of 'Civil Defence' established in 1951 under 1952 Civil Defence Act was given additional task of taking remedial measures against natural and manmade disasters during peacetimes. Later on 'National Crisis Management Cell' (NCMC) and 'Provincial Crisis Management Cells' (PCMC) were established to coordinate plans for emergency response services. These were to coordinate disaster management measures of all concerned department like irrigation, health, agriculture, livestock, food, police, dams safety council and SUPARCO (Pakistan Space and Upper Atmosphere Research Commission). According to this arrangement, Pakistan Army was on call from civil administration for employment when required. Within the planning domains, Government of Pakistan resorted to well known 'National Five Year' plans in 1955 which continued till 2003 and thereafter got converted into 'Ten Year Perspective Development Plan (2001-2011)'.

\section{Post Earthquake 2005 Disaster Management}

Having experienced the fragility of disaster management arrangements during Earthquake 2005, the Government decided to setup an integrated management structure to deal with such like situations. Resultantly NDMA (National Disaster Management Authority) was established and put into operations in 2006 under 'National Disaster Management Ordinance' 2006. Presently it is the apex coordinating body for disaster management starting from recovery and evacuation to post-disaster reconstruction. NDMA also serves as secretariat of NDMC (National Disaster Management Commission) under the Prime Minister, having representatives from concerned ministries of federal and provincial governments.

The setup has been mandated to formulate regulations for disaster management structures in coordination with district, tehsils and town authorities. Therefore NDMA provides institutional and regulatory framework for the overall functioning of national disaster management regime. NDMA has developed 'National Disaster Risk Management Framework (NDRMF) which has been approved by the Government and it also covers 'disaster risk reduction'. NDRMF (as a document) covers proactive activities like national capacity building, disaster risk management, establishing 'Emergency Operation Centres' byincorporating lower tiers of public participation, education and training.

\section{Disaster Management in the Contemporary World}

\section{United States of America (USA)}

USA has an organization with the name of FEMA (Federal Emergency Management Agency) which is pivotal in disaster management all over the country. It operates under the department of Homeland Security. FEMA has 7,382 employees to support American citizens in emergencies to prepare for, protect against, respond to, recover from and mitigate all hazards. Federal Emergency Management Agency, U.S. Department of Homeland Security 500 C Street SW, Washington, D.C. 20472, Emergency Management, , retrieved 17 June 2011.

It acts as part of the larger team comprising federal and local officials, private sector, non-profit and faith-based groups and the citizens.

For the purpose of efficient management, in case of emergency, the entire country is divided into ten regions. Under the umbrella of FEMA, local governments perform the fundamental role in disaster management. The local governments utilise mutual aid agreements with adjacent jurisdictions. The concept is to deal with the emergencies at the most local levels where possible. In the case of 'Incident of National Significance' the Secretary Homeland Security initiates 'National Response Framework' which involves employment of federal resources, primarily integrating those with local and regional level entities. 
Even with the employment of federal resources, the management continues to be functional at the lowest possible levels. The management performs under a network of information sharing about resources, knowledge and extents of damages under NIMS (National Incident Management System). Public awareness and education of the people for emergency responses is undertaken by the Citizen Corps, an organization comprised of volunteer's services. The Citizen Corps operates in 'Community Emergency Response Teams' for teaching basic disaster response skills. In the cases of severe emergencies, the volunteer teams provide emergency support to the conventional emergency services.

\section{United Kingdom (UK)}

UK government adjusted her emergency management following the fuel protests in 2000 and resultantly created Civil Contingencies Act (CCA) 2004. By virtue of this act, it is the Civil Contingencies Secretariat which executes disaster management through regional and local level forums. For efficient management of hazards, CCA focuses on management training, which is primarily conducted at local levels and consolidated through professional courses at the Emergency Planning College. The Convent University conducts diploma, undergraduate and postgraduate level courses / qualifications throughout the country.

Institute of Emergency Management, a charity setup, provides consulting services for government, media and commercial sectors. The emergency management concepts are validated through exercises, one such exercise was carried out near Belfast on 20 May 2007 which involved the scenario of a plane crash. The drills and procedures of all concerned departments were monitored for corrective measures. Cardinal points of UK Government's strategy for disaster management are: centralized coordination, decentralized execution, involvement of local governments, training of citizens and community participation. The point to note is that all execution is done at the local levels by the people through the coordination of local governments.

\section{India}

India has an organization like that of Pakistan i.e. NDMA (National Disaster Management Authority), which operates under the Ministry of Home Affairs. The NDMA is envisioned "to build a safer and disaster resilient India by developing a holistic, proactive, multi-disaster and technology driven strategy for disaster management through collective efforts of all government agencies and NGOs". NDMA is comparatively a new setup with a focus shift from response and recovery to risk management and reduction. Similarly it has a shift from government centred approach to decentralised community participation where Ministry of Science and Technology facilities integration of government resources and local level efforts.

In order to ensure public - private partnership, conduct of emergency training is the first step. For timely reporting of emergency hazardous situations, their planning includes measures like introduction of a single emergency telephone number and fixing training standards and responsibilities during peacetimes. Strength of the policy rests with proactiveness and community participation.

\section{Germany}

Disaster management mechanism in Germany is operative at the federal government level which ensures integration of civil protection programmes. In case of emergency, the fire fighting departments, armed forces, federal police and state police forces get deployed 
under Federal Agency for Technical Relief known as THW (Technisches Hilfswerk). Additionally volunteers / NGOs like German Red Cross, ambulance services and private relief organizations join federal government's efforts at various tiers to deal with the disastrous situations.

The hallmark of their proficient functioning is based upon affective employment of technological and technical means. The departments and organizations dealing with various kinds of disasters are appropriately equipped to deal with emergencies. They maintain a professional approach towards disaster management through utilization of suitable means, mobilization of resources and employment of trained manpower. In order to impart effective training, joint courses at the University of Bonn leading to master's degree known as 'Master in Disaster Prevention and Risk Governance' are organized at the federal government levels.

\section{European Union (EU)}

EU has devised a community based mechanism for civil protection. This mechanism is to facilitate cooperation amongst the member states in the event of emergencies when urgent responses are required. Monitoring and Information Centre (MIC) established at EU levels, plays a pivotal role in the effective functioning of civil protection mechanism. This centre is part of Directorate General for Humanitarian Aid and Civil Protection of the European Commission which functions round the clock and is easily accessible.

MIC provides an access platform to all the member states for utilization of available protection means. In this way, it acts as a hub of communication and provides useful updated information about availability of means required to handle disasters. It also maintains data about the field experts and directs them to reach to the affected areas for dealing with the emergency situations.

\section{Recommendations for a Viable Disaster Management in Pakistan}

\section{Focus Shift from Theories to practices}

Since 1951, when Pakistan faced first flood, the government policies and strategies have been to respond that particular event or calamity, precisely a reactive approach. It was Earthquake 2005, which brought-forth proactive thought process and we created NDMA for disaster management in a holistic manner. Within NDMA, the National Disaster Risk Management Framework (NDRMF) adopted under the policy, included disaster risk reduction, integration of risk assessment, new infrastructural projects and multi discipline approach. Development of the conceptual contours and framework of NDMA is an excellent paper work; however far from implementation modalities and ground realities. Main reasons of such an illusion are as given below.

NDMA is primarily a donor dependent rather driven organization. Its dependence for functioning as an organization remains on UN Habitat, Pakistan Baitul Mall, Ministry of Social Welfare, UNESCO, WHO and relevant ministries at the federal and provincial levels. At the same time in its functioning, NDMA is a subsidiary department of government machinery at the federal and provincial levels. It has neither an integral pool of trained manpower like FEMA nor a functioning parent government development from where it could draw strength to function within formal governance streams. Therefore, an organization with no formal functioning chain/authority and put at contribution of donors can neither develop confidence nor sustain and function as a formal statutory government body. 
For implementation of disaster management measures, NDMA is at the mercy of other departments like district administration, police, law-enforcing agencies, finance, planning and alike. At the time of disasters, those departments have their own agenda; implementation of NDMA measures becomes secondary for them. This makes it a nonfunctional entity at the execution levels.

NDMA, in its present shape is devoid of professionalism; starting from bottom to top. Bureaucratic mindset, it may be the civil services or military, cannot comprehend complexities of disaster management. They need to be trained on modern management and understanding the behaviour of different societies under disastrous situations.

In order to make NDMA proactive in outlook and approach, its foundations have to be laid on doable and implementable modalities. Following is suggested to make it a vibrant and compatible setup.

Chairman NDMA should preferably be a person from civil services or military in active service who had attained some formal training on disaster management, preferably a master's degree from a recognized university at home or abroad. At the same time, he should have some experience of serving in a disaster management setup and dealing with the general public under crisis situations.

Instead of leaving NDMA, a loose arrangement under the Prime Minister, it should function under a ministry, as is the case of USA, UK and India. This is to bring it in the main stream of government's functioning. At the same time, this arrangement would give it a status to interact with the other departments affectively. Wholly bureaucratic setups cannot function as public service delivery mechanisms till the time they are put under accountability through a public / political figure. The suggested arrangements resolve these problems.

In its Annual Report - 2009, NDMA mentioned that it was given least priority while allocating funds. Nowhere in the world such like arrangements have ever worked. Therefore NDMA should have its own budget for the purchase of essential equipments and meeting the recurring expenditure. The budget would also include funds for the immediate relief and rescue operations and rehabilitation of essential services like repair / reconstruction of bridges, restoration of water supply, electricity and sewerage system in the affected areas.

NDMA should also have some authority over the law enforcing agencies like police and Paramilitary forces, when deployed in an affected area, for immediate restoration of traffic control system and guarding against plundering - thefts and other social crimes by the antisocial and anti-state elements under the crisis environments. This arrangement shall make NDMA visible on ground; develop confidence and ownership of relief operations.

\section{Management through Divisions of Areas and segmentations}

The contemporary world manages disasters through the application of modern management techniques like divisions and segmentations, forecasting and monitoring, execution through decentralization, optimum utilization of mechanical means and community mobilizations. Our system of disaster management under NDMA is devoid of such arrangements, therefore we need to focus on the following.

The whole country should be divided into manageable units / areas, may it follow civil administration or police or any other basis of the division. FEMA has divided the entire 
into ten units for effective disaster management. While dividing the areas into disaster management entities, we would require keeping in mind the provincial sensitivities. At the federal levels, the areas can also be identified and grouped on the basis of certain types of disasters like coastal belts, mountainous areas, earthquake areas and those relating to floods.

According to the division of areas, we would require stocking the recovery and rehabilitation means available at short notices. For an effective disaster management, forecasting and monitoring is very essential which needs a permanent organization always on ground. This implies some skeleton organization of NDMA functioning all the times; requires permanently employed manpower like that of USA, UK, Germany and EU.

Training and awareness is a very important segment of disaster management, which is of two kinds. Training of the NDMA staff and workforce to include office management, material resource management, application and operation of mechanical means and handling of casualties at sites. The second part is public awareness about the impending disaster and safeguards at the individual and community levels. Whereas as the former requires formal training and education at appropriate institutes / colleges / universities as is being done in the contemporary world, the later can be conducted through media particularly the electronic medium and workshop at community levels. For general education, disaster management lessons should be added in syllabi at middle and above levels formal school educations.

\section{Disaster Management Specific to its Kinds}

Each category of disaster requires a specific approach for its effective management and accordingly the specialised manpower and equipment. Pakistan has diversity of terrain, weather conditions and densely / sparsely populated areas. Accordingly it faces disasters; natural as well as man-made in different regions. These regions can be easily defined and identified like northern part of the country including river valleys and corridors mostly suffer from torrential rains and floods very frequently, arid / semi arid including parts of Balochistan and Sind suffer from droughts, coastal belts of Sind and Balochistan may face cyclones and windstorms, mountainous regions suffer from occasional earthquakes, densely populated pockets are prone to epidemics especially when civic amenities are disrupted and sparsely populated areas fall short of relief material and services when confronted with disasters. Our strategy for disaster management should therefore focus on the following.

We should have a system of prior identification of the types of disasters in various areas and a system of their forewarning. This would reduce the human and animal casualties. At the same time, our system of forewarning should encompass a mechanism of reaching to the people to enforce protective measures and making the concerned departments' standby to handle the disastrous situations.

As each type of disaster has its own distinct characteristics, accordingly it requires technical means and expertise for their efficient handling. Therefore we need to have relevant equipment, trained individuals and material means for sustainable disaster management. NDMA should have a system of centrally maintaining disaster management means, located at different sites all over the country to allow their employment in a decentralised manner as being done under THW, the disaster management mechanism in Germany.

In this way, we shall reach to a conclusion that accept accidents, fires, collapse of buildings and air crashes, we can always have forehand planning and material means in place for all other kinds of disasters. 


\section{Total Disaster Management - Developing Holistic Approach}

The ultimate objective of disaster management is to bring the situation / environment back to its original state or even better than that so as to make it withstand subsequent suck like situations. Therefore disaster management strategy should be holistic in approach and outlook. It should address issues like identification of the types of disasters in particular areas, system of forewarning, enforcing appropriate protective measures, evacuation of casualties, traffic control, employment of mechanical means, handling internally displaced persons, reconstruction, restoration and rehabilitation.

A comprehensive disaster management would therefore encompass policy development, disaster preparedness - mitigation planning, institution strengthening integration of partners like Emergency Relief Cell in Cabinet Division, National Crisis Management Cell under Ministry of Interior, Provincial Planning and Development Departments, United Nations' assistance and relief agencies, regional organizations including Asian Disaster Preparedness Centre and domestic social welfare organizations and individuals. Disaster management cycle should therefore include activities for pre and post disaster management as under:-

Mitigation strategy basically to prevent hazards from developing into disasters or to reduce their effects. It focuses on long-term measures for reducing or eliminating risks like layout of buildings and improving infrastructures.

Preparedness process would include planning, organizing, training, procurement and maintenance of equipments, exercising, evaluation and effecting improvements. It also includes enhancing capabilities and capacities to prevent, protect, respond, recover and rehabilitate.

Recovery strategy, should primarily aim at restoring the affected area to its previous state i.e. rebuilding infrastructures, re-employment, repairing infrastructures and implementation of mitigation measures that might otherwise be unpopular. In all these phases, community participation should remain our fundamental focus, possible through local governments only.

Similarly there are numerous disaster management setups like emergency relief centre, flood relief centre, civil defence and management authorities at various levels starting from federal to tehisl governments. They have their overlapping functions. There is a need to disband the unwanted and superfluous departments. Opening of so many setups has made the entire process a complex phenomenon, which needs to be streamlined.

\section{Transparent Accountable Disaster Management}

During the devastating floods of 2010, when people of the affected areas, were in dire need of food, shelters and medicines, majority of the international donors preferred to fund private organizations directly, highlighting their trust and faith on those setups instead of government run organizations like NDMA. This is the reflection of our corrupt, sluggish and inefficient mechanism of disaster management under elite setups like NDMAs.

The solution lies in accountability; both i.e. public as well as departmental. When donor organizations see people's sufferings and at the same time officials of these setups in luxurious vehicles and turnouts, they find reasons as why relief funds do not reach to the deserving people, therefore turn towards volunteers and visible transparent departments. Putting NDMA under a ministry would automatically make it accountable to the public. For departmental accountability, it would get out of the shadow of the Prime Minister's Secretariat and accordingly should be placed under prevailing mechanism of audits and accounts. 


\section{Disaster Management Training}

Disaster management training is essential part of the entire process which needs institutional approach. University of Copenhagen conducts training for master's degree in disaster management programme. The formal education should include disaster risk reduction, response and recovery. National Institute of Disaster Management (NIDM), established in 2009 has been mandated to work as a learning centre for government officials, private sector, media, NGO and community organizations for developing policy guidelines, enhance the capacities through research and training. Objectives of NIDM revolve around curriculum development, undertaking research, developing partnership with national and international institutions, publish research journals etcetera and maintain database of disasters in the country. During 2009, it undertook number of workshops and training schedules, all focused on government officials and NGOs.

NIDM shall remain a system on papers only till the time; it is developed to conduct degree related disciplines. There is a need for NIDM o develop into multi Discipline University, capable of conducting masters' levels education on relevant disciplines like risk management, information management, resource management and management of technical means. The university may also conduct studies on geology, geography, history and psychology, all relevant to disaster management. This shall provide NDMA a learner's forum for research studies in the relevant fields as well as trained people for employments.

The fundamentals of our public awareness strategy should focus on 'protect yourself, your home and family and take protective measures'. It basically relates to what should the people do, if God forbids, some disaster occurs; the safeguards should become part of the traditions and training of the society, similar steps have been taken by Assam Government in India. The aim is public awakening, while remaining within or very close to their traditions and customs. In a holistic training of the society as well as that of individuals, the principles of comprehensiveness, progressiveness, integration, collaborative and flexibility should form it basis.

\section{International, Regional and National Donor Agencies}

NGOs can play an effective role in response to disaster particularly during the evacuation and rehabilitation stages. They need to be integrated in the overall plan exploiting their positive points like grass roots links, inherent flexibility, innovative and adaptable approaches, and expertise - cost effectiveness. Similarly their shortfalls or limitations have to be kept in view like their limited institutional capacity, resource and financial constrains, isolated working, limited field sustainability and compatible understandings.

The employment of these organizations can assist in capacity building to include construction of emergency shelters and first aid training etcetera. In capacity building, reliance should be rested on the local resources. The NGOs can also contribute in long term measures like plantation of mangrove forest to create a natural barrier against floods in coastal belt areas and inculcating awareness about environment protection / preservations

\section{Application of Technology as Disaster Management Tools}

German strategy of disaster management can be quoted as an example for the application of technical- technological means. The modern science and management provide numerous means of facilitating crisis management. It includes maintenance of data banks for availability 
of information about the recovery and relief materials under disastrous situations, locating trained individuals for evacuation operations and mobilization of rehabilitation resources. Emergency Management Information Systems (EMIS), Hospital Incident Command System (HICS), Internet, Cable networks, Media of all kinds, Mob phones SMS systems and Websites are the best available tools for disaster management. The only need is to coordinate their use for expeditious extraction of relevant information and making use of those means.

With so much of material available for disaster management all over the world, the requirement is to work out guidelines and safety tips for each type of disaster and made public in print as well as electronic media. Assam Government in India has done it in a much simple way which includes small booklets containing tips for various kinds of disasters. For example guidelines in case a stove busts in the kitchen and fire breaks out, precautions in case of heavy rains / floods and so on. Since we face variety of disasters starting from road accidents - dengue fever to earthquakes, we should develop sufficient literature containing precautionary measures, protective guidelines and tips to avoid damages from disaster. These booklets should be made available to the people at bookstores, railway stations, airports and other public places free of cost or with only the printing cost.

\section{Conclusion}

A common observation during the crisis in Pakistan has been that it is not the deficiency of the means but failure of the system to make appropriate use of the resources available which leads to casualties and damages. So, mostly we fail in management of disasters, may it be beforehand protective measures, recovery and evacuation or rehabilitation processes. Management of available means provides us the solution.

\section{References}

Oxford Talking Dictionary, 1998, The Learning Company, Inc.

Henry George Liddell, Robert Scott, A Greek - English Lexicon, Reference: http://www.perseus.tufts.edu/cgi-bin, June 20, 2011.

Aster, Henry George Liddell, Robert Scott, a Greek - English Lexicon, retrieved from http://en.wikipedia.org/wiki/disaster, modified on 21 June 2011.

United Nations Organization, International Decade for Natural Disaster Reduction, DHA/IDNDR 1992 and Natural Disasters: Protecting vulnerable communities, IDNDR Proceedings of the Conference, London, 13 - 15 October 1993.

Natural Disaster Organisation, Australian Emergency Manual, 1987, Canberra.

Oxford English Dictionary, 1983.

Richard Barret, Vocational Business: Training, Developing and Motivating People Business and Economics - 2003, p51.

George R. Terry and Stephen G. Franklin, Principles of Management, Eighth Edition: Homewood, USA, Richard D.II Wine Inc. 1982, p 4. 
Quarantelli E.L. Where we have been and where we might go, 1998, what is a Disaster? London: Routledge.pp146 - 159, retrieved http://en.wikipedia.org/wiki/Disaster, 10 June 2011

B. Wisher, P. Blaikie, T. Cannon, and I. Davis, At Risk - Natural hazards, people's vulnerability and disasters. Wiltshire: Rutledge. ISBN 0-415-25216-4, http://en.wikipedia.org/wiki/Narural_disaster, 20 June 2011.

United Nations, TWG Working Group Meeting, Disaster Risk Management, 17 May 2007, Report compiled under 272- 273/ Disaster Management Programmes for Priority Countries, South Asia,

Demographics of Pakistan - Wikipedia, the free encyclopaedia, http://wikipedia.org/wiki/demographics_of_Pakistan,retrieved on 24 June 2011.

United Nations Development Programme, Human Development Report 2009, http://www.businessweek.com/globalise/content/apr2010/gb2010044_082450.htm retrieved 21 June 2011.

B. Wisner, P. Blaikie, T. Cannon and I. Davis, At Risk-Natural hazards, People's vulnerability and disasters, Wiltshire: Routledge, ISBN 0 - 415-25216-4, http://en.wikipedia.org/wiki/Disaster, retrieved 21 June 2011.

Himayatullah Khan, COMSATA Institute of Information Technology Abbottabad and Abururab Kahn, collaboration Institute of Development Studies Agriculture University Peshawar, Natural Hazards and Disaster Management in Pakistan, MPRA, 12 October 2008, http://mpra.ub.uni-muenchen.de/11052/

WCDR, A Review of Disaster Management Policies and Systems in Pakistan, January, 2005. United Nations, 274/ Disaster Risk Management Programmes for Priority Countries, South Asia.

National Disaster Risk Management Framework (NDRMF), 2007.

Government of Pakistan, A Review of Disaster Management Policies and Systems in Pakistan, January 2005, Islamabad.

Federal Emergency Management Agency, U.S. Department of Homeland Security 500 C Street SW, Washington, D.C. 20472, Emergency Management, http://en.wikipedia.org/wiki/Emergency_management, retrieved 17 June 2011.

Mock plane crash tests NI crews, BBC News, May 20, 2007.

Emergency Management in India, http://en.wikipedia.org/wiki/Emergency_Management modified on 20 June 2001.

Civil Protection - The Community Mechanism for civil protection. Ec.europa.eu. http://ec.europa.eu/echo/civil_protection/civil/prote/mechanism.htm Retrieved 29 July, 2010.

United Nations, Disaster Management Programmes for Priority Countries, South Asia, Reports $280-284$.

Disaster Management, The Nation, 23 November 2010. 
The Nations, Disaster Management, Published: November 23, 2010. Disaster Management/ Pakistan/ News/ Newspaper/ Daily/ English, http://nation.com.pk/pakistan-newspaper-dailyenglish-online

Master of Disaster Management, University of Copenhagen.

http://www.mdma.ku.dk/masters_programme/

Government of Pakistan, National Institute of Disaster Management, Relief web, 15 February 2010, http://reliefweb.int/node/345325.

Ibid.

Karimganj District Resource Inventory (India disaster Resource Network), http://karimgani.nic.in/disaster.htm, 11 July 2011.

Disaster Management, Assam Government, http://karimganj.nic.in/disaster.htm

We never look at our competitors' products. Why should we assume they know what they're doing? We push our managers to be creative, challenge them not to beat the competition but to rewrite the rules.

- Micheal Bloomberg, founder in the 1980s of US information services firm Bloomberg. 